\title{
A Game of Genders: Comparing Depictions of Empowered Women between A Game of Thrones Novel and Television Series
}

\author{
Rebecca Jones $^{\mathrm{a}}$
}

\begin{abstract}
The main women in George R. R. Martin's novel Game of Thrones, first published in 1996, and the adapted television series in 2011, are empowered female figures in a world dominated by male characters. Analyzing shifts in the characters' portrayals between the two media conveys certain standards of the cultures for which they are intended. While in the novel the characters adhere to a different set of standards for women, the television series portrays these women as more sympathetic, empowered, and realistic with respect to contemporary standards. Using literary archetypes of queen, hero, mother, child, maiden and warrior and applying them to Cersei Lannister, Catelyn Stark, Arya Stark, Sansa Stark, and Daenerys Targeryen, provides a measure for the differences in their presentations. Through the archetypical lens, the shifts in societal and cultural standards between the novel and series' airing make apparent the changing pressures and expectations for women. By reading the novel and watching the series with these archetypes in mind, the changes in gender norms from 1996 to 2011 become clear. The resulting shift shows the story's advances in the realm of fantasy in relation to the American society that consumes it.
\end{abstract}

Keywords: English, Film Studies, Women and Gender Studies

\section{Introduction}

The genre of fantasy has a long and sordid history in its depictions of women. Even today, female authors and positive female protagonists are still scarce. This is in part because the genre battles not only societal norms, but also the chivalric standards and gender roles of medieval times, which it often emulates. Knights and damsels-in-distress are often touchstones for male and female characters. Presently, "Feminist philosophy [...] sees chivalry as oppressing women by formulating a specific role that not all women want for themselves, and, further, by devaluing the role that women are supposed to play." Recent fantasy novels have started to counteract this trend through the writings of female and male authors alike, refuting the former chivalric expectations for women within the genre by allowing women greater prominence within their novels. In the novel, A Game of Thrones by George R. R. Martin, the modern reader encounters Cersei Lannister, Catelyn Stark, Sansa Stark, Arya Stark, and Daenerys (Dany) Targaryen spanning a spectrum of female roles, ages, ranks, and personalities. In 2011, the novel was adapted for television by the Home Box Office (HBO) network. The first season was ten episodes long and covered the entirety of this first novel. While some essays have been written, looking at the series and examining them through various lenses ${ }^{2}$, at the time of writing there are no articles published academically on either manifestation of this story regarding these characters. Each of the aforementioned women is empowered through her political rank within the world Martin creates, while also possessing a strength of her own, which manifests through the various trials she faces. These women exhibit the archetypal traits of Queen, Mother, Maiden, Warrior, Hero, and Child, some exhibiting multiple aspects or shifting aspects as the story progresses. While the series is a close adaptation of the novel, by noting the variations in the depictions of the aforementioned women, one sees the changing standards for women conveyed by the differences in portrayal between the two media, utilizing the lens of their respective archetypes.

\section{The Women}

\subsection{Cersei Lannister: Shadow Queen and Mother}

Cersei Lannister is the most powerful woman in both novel and show, and by far the most feared. Martin introduces her to the reader as being "The Lannister woman""3 whose "“pride is said to grow with every passing year." ${ }^{4}$ Presenting her character in this manner, he conveys her personality and cements it with little deviation for the rest of the novel. She is seen through the perspectives of the other characters, never allowed a perspective chapter as the other women examined are. For all the fear she commands, King Robert, her husband, is still able to command her. When the royal party arrives at Winterfell in the beginning of the story, King Robert wishes to pay respect to the dead Lyanna, his lost love. However, when Cersei asks Robert to wait, as the party is tired from their travels, he looks at her then turns to do as he intended. ${ }^{5}$ Martin establishes from the beginning the relationship between the king and queen, one of public dominance and submission, respectively. The show plays out the scene in a similar fashion with the queen begging Robert, "We've been riding for a month my love, surely the dead can wait," rather than be silenced with a look from Robert, she is ignored completely in front of the assembled Stark household. This difference sets the standard for the show with regard for how Cersei is presented. While the novel insults her, the show gives her a voice, yet still conveys how little power she has in this male dominated world. David Benioff and D.B. Weiss, creators of the show and writers of many of this first season's episodes, introduce her in the first episode before the audience knows who she is. They know only that she has something to 
hide from the king, and her brother, Jamie, is a part of it somehow. She asserts herself throughout the series as both a Mother figure concerned about her children with little regard for others as shown by her scolding Jamie for his failed attempt to kill Bran in the show, ${ }^{7}$ and the latter trial of Arya in both versions. ${ }^{8}$ Yet, throughout the novel and show, she presents herself as strong and unafraid. Though a woman, she invokes fear in men's hearts and has the respect of all at court. Thus, the audience sees her as both Mother and Queen, but tainted by Shadow aspects, as her actions and motivations are not pure and result in the harm and suffering of others.

Four major scenes in the television show redefine Cersei's character and depict her as developed and complex, more so than Martin's presentation of her in the novel. The first of these scenes occurs in the episode "Kingsroad," when Cersei goes to the comatose Bran's room and consoles Catelyn telling of her own firstborn's death. The novel likewise mentions Cersei's first child, but much later and with a far different tone. When she tells Catelyn the story of her stillborn son in the show, it is with a quiet, somber voice. This change redefines her character and in the show's storyline gives her a different attitude and motivation than that of the poisonous, bitter Queen of the novel. This moment hints at the seeds of love she once had for Robert that have long since die: how there was a time when she bore his children, and rather than intentionally killing the child, as she does in the novel, he is already dead, and foreshadows the fate of her love for Robert. This moment gives the viewer some ground upon which to understand Cersei's later actions, as well as presenting her character as that of a Mother figure not just the Queen seen until now.

The second moment shows her with her son, Joffrey, and her actions and words during this scene define her character as a Shadow Mother. The viewer is shown the mothering side of Cersei as she bandages her son, but that nurturing side turns sour as she tells Joffrey, "Someday you will sit on the throne and the truth will be what you make it." 9 She essentially is encouraging him to lie, just as she does, to get his way. To have her so coddle Joffrey saying, "You are my darling boy and the world will be exactly as you make it,"10 the audience feels a sense of dread as these two corrupt, deceptive, and selfish individuals are the ones in power and able to control the fate of the kingdom. Her final words to Joffrey solidify her character as a Shadow Mother: "“[e]veryone who isn't us, is an enemy.","11 The show presents this scene not only to reveal her nurturing side, but also to show her type of nurturing is twisted, and shapes her son into a monster who manifests at the end of the show and novel as being beyond her control. The novel, lacking this scene, does not present her as nurturing or motherly, only as a powerful schemer, feared by the men of the court and kingdom. As a Shadow Mother, she shapes her son to be a king who will destroy the kingdom with his selfishness and cruelty; as a Shadow Queen, she uses her power to get her way and manipulate others to maintain her control and destroy her enemies. Only in the show does her Mother aspect ever truly manifest.

The next scene shows an interaction between Robert and her, revealing the truth of what their relationship has become, and presents Cersei in a human light. This is the only moment in the show when the two talk without getting upset or leaving the room; the novel has no similar moment. It presents to the viewer a human relationship. Robert muses, "Sometimes I don't know what holds [the kingdom] together,"12 to which Cersei answers, "Our marriage,"13 and they both laugh. Robert continues looking at his wife and asks, "How long can hate hold a thing together?" "She responds, "Well seventeen years is quite a long time," and then continues, "I felt something for you once. ... Even after we lost our first boy. Quite a while, actually." 15 Robert tells her he knew, but that there was never a chance for them to have real love. ${ }^{16}$ This back and forth shows not only the honesty with which they are finally speaking, but also that Cersie is not the heartless, bitter thing the novel presents her as being. She confesses to care about Robert and confirms this caring later to Eddard (Ned) Stark. In this scene, Cersei and Robert are civil and though both are unhappy with the current state of things, they are selfless enough to stay married for the sake of the kingdom. This shows the Queen aspect of her character, but the taint of their imperfect relationship, the viewer's knowledge of her incestuous relationship with Jamie, the illegitimacy of her children, and her attempts to kill Robert all reveal the Shadow aspect of her character. As mentioned before, the absence of this scene from the novel presents Cersei negatively, as a creature of pure, bitter evil. The show develops her character and presents a complex, flawed person.

While Robert and Cersei were cordial in the scene above, they are more commonly at odds. The novel is rife with moments when Robert says "Quiet, woman,"17 silencing Cersei, but the most memorable moment between them is when Robert hits her. In this moment, Cersei mocks his loyalty to Ned and is hit for saying, "you ought to be in skirts and me in mail." 18 After threatening her into silence, she leaves and he turns to Ned saying, "YYou see what she does to me, Ned. . . . My loving wife. The mother of my children. . . . I should not have hit her. That was not . . kingly,' He stared down at his hands, as if he did not quite know what they were." ${ }^{19}$ This moment plays out identically in the show. The fact that the viewer and reader have been encouraged to loathe Cersei up to now does not help them pity her in this moment, yet they feel Robert's action has crossed the line. Robert's words to Ned serve as an apology, but saying something is wrong afterwards does not excuse the action. Not only that, but Robert blames Cersei for provoking him. This seems to mirror modern society's tendency to blame the victims of rape and molestation claiming their somehow earned it, rather than see the women as victims of a crime. However much Cersei's role as Queen and the power she possesses allows her to speak and act on an equal level with the men around her, Robert's actions reveal that Cersei is still, for all her power, dominated by men. This reflects the changing standards, not only for character development, but also in depictions of women in fantasy. In his novel, Martin presents a flat villain, but in the show her character is developed, allowed a voice, and conveys her perspective. Though not excusing her actions, the show gives more reasoning behind her choices than in the novel.

Cersei's nature as both Shadow Mother and Queen is present when she meets with Ned, and the truth of her relationship with Jamie is confessed. This one scene occurs in both media, but with some differences that redefine her character. In the show, Ned asks, if Robert has hit her before and she tells him that, no he had not as "Jamie would kill him" if he had ${ }^{20}$. 
When he asks why she hates Robert so much she answers, "Hated him? I worshiped him. Every girl in the seven kingdoms dreamed of him but he was mine by oath. And when I finally saw him on our wedding day . . . it was the happiest moment of my life. And that night he crawled on top of me stinking of wine ... and whispered in my ear, 'Lyanna.' Your sister was a corpse and I was a living girl and he loved her more than me." 21

This moment reflects her earlier confession to Robert that she did, once, love him, but in these lines the viewer sees the reason why they could never have been happy together: Robert's obsessive love for Lyanna. Finally, Cersei ends their discussion after Ned informs her he is going to tell the king about the illegitimacy of her children. She challenges him, "And what about my wrath Lord Stark?"22 showing no fear in her face regarding what he has said showing that she feels secure in her position and views Ned as a threat, but not one powerful enough that she cannot stop him.

The novel has some differences in its presentation of this scene. Most of these differences are due to it coming from Ned's perspective. Thus, the reader sees Cersei through his eyes and mind. Cersei's response to Ned asking if Robert had hurt her before changes to, "Once or twice.[ . . . ] Never on the face before. Jaime would have killed him, even if it meant his own life." ${ }^{23}$ Her answer about her first child by Robert differs from the stillborn spoken of in the show. She tells Ned, "'Your Robert got me with child once [...] My brother found a woman to cleanse me. He never knew. If truth be told, I can scarcely bear for him to touch me, and I have not let him inside me for years." 24 Considering her attitude towards Robert here, it seems strange that her honeymoon plays out in the novel in a similar manner as it does in the show. However, a large difference between the two media is her attitude during the scene.

In the show, she is calm the entire time and in control. The novel, however, paints a different picture. She is still the strong woman but she shows her anger and even offers to have sex with Ned as a way of resolving their differences. ${ }^{25}$ Ned mocks her advances and she mocks his honor, reminds him of his own bastard, and asks how he is any different from the rest of them. ${ }^{26}$ Ned jibs in return, "For a start . . I do not kill children," 27 in reference to Jamie's attempt to kill Bran. Cersei's parting words show her regaining her composure at the end: "And what of my wrath, Lord Stark?" 28 This scene is possibly the most important moment in both the novel and the show as it is the culmination and tipping of the drama's action. However, future events aside, the things revealed within these passages and scene define Cersei as both Queen and Mother and show the part of her life that has caused her to be who she is. The difference of a stillborn son versus an aborted one, and her overall tone in connection with Robert throughout the novel's narrative, shows her as bitter and without love for her husband. However, both versions present the audience with the knowledge that she did love Robert once and that he destroyed that love through his actions and neglect. Another great difference that tells much about the time in which each medium was released and audiences they cater to is the king's abuse of Cersei. He hits her in both versions; however, the novel states that Robert has done this before whereas the show asserts that he would not dare. This change in tolerance for domestic violence reflects a sharp shift in the standards towards abuse. Hitting Cersei once is one thing, but a history of beatings is another; Robert would lose much of the audience's sympathy if he were to beat Cersei regularly. The novel's Robert is not depicted as being as endearing as the show's as television has to work harder to keep its viewers interested and maintain the integrity of its characters; thusly the characters are held to a higher standard than the novelistic versions of them.

This scene, while presenting the difference in standards of each media's respective time, also serves to show Cersei's Mother aspect through her love for her children, but also the extent of the Shadow in her, as she will do anything for their sake, even kill another child ${ }^{29}$ and anyone who threatens the truth of their birth. The novel's version not only presents a woman who is beaten by a husband she detests, yet who is not ashamed to seduce men to get her way as shown by her advances towards Ned, who quickly scorns and mocks her actions. Ned also belittles her by his assertion that other women loved Robert, so clearly she should too. ${ }^{30}$ While the show presents her as strong, unashamed, and unafraid of Ned's threats, Martin presents her as pathetic, disgusting, and less than Ned in the novel. The differing lines in the novel and the actions presented in the show are what shape the difference between Cersei's two representations and allow her to be stronger in the show.

\subsection{Catelyn Stark: Warrior and Shadow Mother}

Although Cersei may hold more political power in the world of the story, Catelyn is her match, and counter image. Cersei has moments, though only in the show, when she exhibits positive traits, while Catelyn's negative traits, presented in both versions, are her attitude and treatment of Jon Snow, Ned Stark's bastard, and her motherly devotion to her children. In this, Catelyn falls short of perfection. She is a Mother, as seen by her devotion to her children and her actions to keep them safe. However, she is not a perfect one. Rickon, her youngest, is neglected by not only her, but by his father, and is seemingly forgotten by his siblings as well. There are interesting differences in Catelyn's presentation in the show versus the novel. Her treatment of Jon is only slightly less cruel as the show does not get into her head to see the extent to which she loathes the boy. She is also slightly different in her attitude towards Ned becoming the Hand of the King. At first, she wants him to stay with her in both versions, but once they learn of Jon Arryn's death her attitude changes. In the novel, she wants him to go, thinking that it will be the only way to keep them safe. In the show, she is still against him leaving, going so far as to cite the fate of his father and brother who died when they were summoned by the previous king. This difference shows that rather than being more fearful of what the Lannisters will do if Ned does not go, in the show, she cares more about Ned's safety and whether she would ever see him again. She also pleads with him more in the novel not to take her children from her, especially Bran who is her favorite. Thus, when Jamie pushes him and he is in a coma, she blames herself for wishing him to stay. She becomes bitter towards Ned after this in the novel, not wanting him to leave. The show reflects this as well when she reminds Ned how he left her seventeen years ago and returned with Jon. ${ }^{31}$ Ned answers, "I have no choice." 32 To which Catelyn counters poignantly, "That's what men always say when honor calls . . . I can't do it Ned, I 
really can't,"33 but Ned replies, "You can, you must." ${ }^{34}$ This moment reveals the strength of their relationship, and shows how the love that Catelyn holds for Ned is as much a driving force for her as the love she bears their children.

Later in the show, after they capture Jamie, and the men at council decide to hail Rob as the King in the North, she goes out to see Jamie and talks with him, though first she hits him with a rock as he offers to warm her bed and makes a jibe at her recent widowhood. ${ }^{35}$ This moment does not occur in the first novel, but Catelyn does assert her aggressive nature by countering one of the council members, who said she was of "the gentile sex" 36 by replying,

"Give me Cersei Lannister . . . and you would see how gentile a woman can be. . . Perhaps I do not understand tactics and strategy . . . but I understand futility. . . . I want my daughters back, and the queen holds them still. . . . I want [Rob] to live [his] life, kiss a girl and wed a woman and father a son. I want to write an end to this. I want to go home, my lords and weep for my husband."37 She is not a violent person and has "no love for swords" "38; thus, she wants her son to be safe and for them to go home before things become more than they can handle. Alas, the men want war and ignore her words, and in that moment "she saw his true bride plain before her now: the sword he had laid on the table. Catelyn was thinking of the girls, wondering if she would ever see them again[...]"39 While the men are thinking of the battle and to whom they will swear allegiance, Catelyn still remembers why they set out for war, remembers her children are in danger and that the battle they have won has not changed that fact.

In the show, when they learn of Ned's death, she tells Rob, "We have to get the girls back and then we'll kill them all." 40 She is a Mother to the end, and while she would gladly kill Cersei, she knows when violence is futile. Catelyn is yet another victim of the chivalric standard of her world; she "slit a man's throat and pried a dagger away from her own by grabbing the blade with her hands and biting her attacker, yet people still considered her as vulnerable as any other woman. Men and women are held to the ideals of knight and ladythe protector and the protected-regardless of an individual's need for such protection. ${ }^{" 41}$ The Catelyn of the novel is more passive and less inclined towards violence, yet in the show she repeatedly presents a more aggressive and violent nature reflecting a more masculine personality and revealing the Warrior within her. It seems interesting that in the novel Catelyn speaks at this last council meeting, whereas in the show she is silent, showing only by her eyes' uncertainty where this new course of action will lead. This moment seems to show the attitude that the men hold towards her words now, whereas in the novel she is able to speak but they disregard her; it is hard to tell which situation is worse.

This moment shows the audience how little women are regarded when it comes to matters of war. Whereas before the battle, Rob sought her council, afterwards it seems he has little esteem for his mother's advice spoken or unspoken. He is more caught up with his newfound power as King in the North. Where Cersei raised her son to be selfish and cruel, Catelyn raised Rob to be wise and just, yet in both cases once their sons attain the power of kingship they seem to no longer regard the words of their mothers. Joffrey ignored Cersei's warning not to kill Ned; now Rob will not hear the council of his mother and so heads into war. Catelyn asserts, "“[a] woman can rule as wisely as a man,",42 yet the only woman ruling by the end of the book is across the sea. This is a world dominated by men, where Cersei and Catelyn are the two most powerful women in it, yet they are dominated and overshadowed by sons who would be kings. Catelyn goes through so much: "had fought to keep herself strong, for Ned's sake and for this stubborn brave son of theirs. She had put despair and fear aside, as if they were garments she did not choose to wear...but now she saw that she had donned them after all." ${ }^{43}$ She is strong for her family, yet she is still fallible, especially concerning their safety and wellbeing. She is not perfect but she is strong and tries to do the right thing to keep her family safe. She is a Mother who dons the armor of the Warrior for the sake of those she loves.

\subsection{Sansa Stark: Maiden and Ingénue}

We are introduced to Sansa in the novel through Arya's eyes. The first thing said of her is, "She did everything prettily." ${ }^{44}$ Sansa is the quintessential chivalric princess: "All she wanted was for things to be nice and pretty, the way they were in the songs." 45 This idealism causes her misery later in the novel as her delusions regarding Joffrey eventually result in her betraying her father to his death. Sansa is a remnant of old female fantasy characters. Her innocence and damsel demeanor fit well into the traditional chivalric female characters who passively await the active men's returns or rescue. However, while Martin uses her as an echo of these past female roles, by the end of the novel and series Sansa develops and awakens to the reality of the world and finds it far darker than the beautiful songs she loves. Her story is very much one of coming into her womanhood and leaving her innocent childhood behind. She is betrothed to Joffrey, but sees her husband-to-be with open eyes and knows she will have to be strong if she is to survive.

Throughout the story Sansa is the embodiment of the perfect Maiden, going so far as to name her direwolf Lady as a direct reflection of this fact. The other characters are not blind to her behavior and Queen Cersei encourages it as much as she can, favoring Sansa at every opportunity. Throughout the show, Sansa's character fits well with the image created in Martin's novel and the actress, Sophie Turner, though thirteen to the novel's original age of eleven, is beautiful and plays the ingénue well. She does not have many lines compared to the whole chapters told from her perspective in the novel, resulting in the audience disliking her a bit, taking Arya's side more often than not, as she is presented in a more sympathetic light. To a modern audience, seeing Sansa's perfect ingénue character is almost disagreeable or at least considered pathetic due to her idolization of Joffrey, and how often she acts like a spoiled child. When Joffrey is hurting and threatening to kill Mycah, then later Arya, it is not for her sister Sansa worries but rather her picture of how things should be. She cries, "You're spoiling it, you're spoiling everything!" 46 When Arya goes after Joffrey to defend her friend, Sansa cries, "Arya leave him alone" 47 rather than telling Joffrey to stop and not hurt her sister. There is little difference between Sansa's representations in the novel to those on the screen. The only exception is that the audience does not hear her constant romantic longings for Joffrey, her obsession with the old songs, and wishing everything to be so simple and perfect. Modern audiences would have little sympathy for or interest 
in a character like that; they might think her annoying, or at the very least pitiable. Of all the major female characters of the story, she is the weakest.

Sansa is redeemed for both the reader and the viewer at the end of the story, however. Sansa holds onto her romantic ideals and delusions right until the very end when her beloved Joffrey calls for her father's head. After this moment, Sansa's eyes are opened, and she is disgusted where before she was entranced. ${ }^{48}$ She can no longer rationalize or blame the queen or anyone else for his actions, her image of heroes and a chivalrous world are shattered so she wishes "she could hurt him ... that some hero would throw him down and cut off his head. But a voice inside her whispered, There are no heroes. . . 'Life is not a song, sweetling,' . . . In life, the monsters win." 49 Showing how ingrained the chivalric standard is in her character that while she wishes to actively stop Joffrey, she first wishes a man would do so for her. Not only is her father dead but her husband-to-be has her hit when she displeases him, ironically following in the footsteps of Robert. Now "the darker side of chivalry, where fully armored adults hit defenseless children, kings rape their queens, and anointed 'knights' are not knights at all" ${ }^{10}$ becomes all too real for her. She finally overtly defies Joffrey telling him, “'Maybe my brother will give me your head",51 in response to Joffrey's threat to add her brother's head to those of the loved ones he has already killed. For her to show such defiance makes the audience feel a smug satisfaction and pride that she has finally woken up and now defies that which she had previously worshiped. This defiance earns her a place among the empowered women of this story.

In both versions, at the end, she contemplates and almost throws Joffrey off a parapet, killing herself but possibly saving so many others. However, the Hound prevents her. This intention reveals Sansa's progression from a passive selfcentered child, to an active self-sacrificing woman who now sees reality for what it is and must play the game in order to survive in her new role as queen-to-be. She is a fool no longer and her future promises to be dark, but she now seems to possess the strength of character to survive and possibly act in the name of those she loves even if it means sacrificing her own life. This change sets her apart from those fantasy women who are one-dimensional, wishing for someone to help them but doing nothing for themselves. Sansa will have to practice deception to literally keep her head in Joffrey's court, something a passive chivalric maiden could not accomplish.

\subsection{Arya Stark: Child Hero}

Arya is Sansa's opposite in all things. Where Sansa is the embodiment of the chivalric standard for women, Arya is the embodiment of the modern feminist standard for women. She wants equality and to be allowed to do anything that men do within her world: "Arya took after their lord father. [...] It hurt that the one thing Arya could do better than her sister was ride a horse. Well, that and manage a household. Sansa had never had much of a head for figures." 52 This introduction establishes Arya as being associated with masculine things from the start. Connected with her father, shown to be good at math and riding, both things that men are supposed to excel at, but inept at the traditional female tasks, Arya is the quintessential tomboy. For all her transgressive tendencies, she is often denied the equality she yearns for as others want to keep her confined within the limitations of their standards for women. Some of these rebukes come from her father. When he finds her sword, Needle, he says, "Little ladies shouldn't play with swords," 53 to which Arya replies, "'I wasn't playing and I don't want to be a lady." 54 Ned knows Arya is not like Sansa, yet for all his leniencies towards Arya's actions and inclinations, he somehow expects her to conform to their society's standards for women. While finding her practicing in the castle's halls she asks him, "Can I be lord of a holdfast?" and says, "You will marry a high lord and rule his castle, and your sons shall be knights and princes and lords." ${ }^{.56}$ Arya replies, "No. That's not me." ${ }^{\text {"57 }}$ Arya has no doubts about who she is and what she wants to do with her life, yet she lives in a society that, while having empowered women like Cersei and Catelyn, still does not allow them to bear swords and fight as equals to men.

Arya in the show is even more of a tomboy than she is in the novel. We first see her looking out at the boys practicing archery and her brother Bran having trouble shooting well. When he goes to take another shot, another arrow hits the bull's-eye, and the camera turns to show Arya behind Bran with a smug, satisfied smile on her face. Ned had only moments before asked the older boys in the yard which of them was a marksman at ten, by way of encouraging Bran. ${ }^{58}$ Thus, to have Arya hit the bulls eye the show presents her character as being not only good at male activities, but also excelling at them. ${ }^{59}$ In the novel, she only dreams of practicing and training with the boys. She talks with Jon about fighting and even then asserts her ideals of feminine equality to him saying, "The woman is important too! . . Besides if a girl can't fight, why should she have a coat of arms?' Jon shrugged. 'Girls get the arms but not the swords. Bastards get the swords but not the arms." 60 Thus, Martin shows the connection within a chivalric society between the discrimination that bastards and women face. The inequality of women within this society assigns them a place and forbids them to leave it.

Arya's interactions with Jon shows another side of her personality, which makes her so sympathetic and endearing to a modern audience, she is kind to the outcasts and the lowly. While her sister scorns Jon because he is a bastard, Arya loves him and treats him like a brother without care for his illegitimacy. She also sits with the soldiers and makes friends with anyone. While on their way to King's Landing, Arya explores with Mycah every day, coming back bruised and cut, but with a smile on her face. She does not act properly or with decorum, but for a modern viewer and reader she is brilliant and endearing as there is nothing she does that is intended to make the audience or reader dislike her. She acts the part of the Hero, defying the odds against her, challenging the cruelty of Joffrey and the Queen, seeing their evil and immediately disliking and distrusting them. She does not discriminate against others whatever their social ranking may be, but only doing so after their actions earn it. She is not yet disillusioned about reality and the cruelties of war but sees the heroes of old and wishes to also make her mark on the world.

For all her longing to have the rights and freedom of men, she never once denies her gender. Multiple times in the story, she is called boy but each time she corrects the speaker. When she first meets her sword master, she is told, "Boy girl, 
you are a sword that is all." ${ }^{\text {61 }}$ This serves to emphasize to the audience that gender does not matter in reality, so it should not matter in society. Arya's constant transgressive nature shows the audience an alternative to Sansa's hyper femininity, Arya is a girl who performs masculine actions but retains her femininity, that is, until she is a wanted person.

After her father's death, a member of the Nightswatch, a man loyal to Ned, takes in Arya. He gets her out of the capital by cutting her hair and, in proper warrior-woman fashion she must now play the boy if she wants to get home alive. This chain of events follows the fate of so many fantasy women. Often the only access into the world of swords and equality is for the woman to deny her womanhood and play the man in order to train, and eventually become a warrior. The repetition of this motif reflects the society that these stories come from. Even today, women are not equal with men, and thus the only way for them to become so is for them to play the opposite gender. The reflection of this fact in literature, especially fantasy, emphasizes the long history of inequality women have suffered from, and the sad truth of the lengths they go to in order to obtain equality. Arya's future is unknown at the end of the story, but the audience is hopeful and knows she will be strong and fight to the end.

\subsection{Daenerys Targaryen: Warrior Queen and Mother}

Daenerys, called Dany, is an exiled queen who never saw her country. Raised by her brother in a semi-incestuous relationship, and constantly told they must return home to reclaim what is theirs, he indoctrinates her to share his ambition and goal of obtaining the Iron Throne. Dany and her brother, Viserys, are trying to get an army and return home. In order to obtain this army "Viserys scheme[s] to sell her to a stranger, a barbarian." 62 Throughout the novel and show, this trade of women occurs: "For men, it is often war that defines them ... For women, definition comes through abduction, forced marriage and rape" ${ }^{, 63}$ : Dany experiences all three when she is sold to Kahl Drogo. The wedding feast is much the same between the two versions of the story, but the depiction of the wedding night differs in one aspect that changes the whole tone of the scene.

In the novel, their first intercourse is consensual but in the show, it is presented more like the rape of a terrified young girl. In the novel, Dany is thirteen when she is wed and conceives a child by fourteen; the show never tells the viewer how old she is, but Emilia Clark is in her mid-twenties. The show avoids the age difference that occurs in the novel as well as the social taboo that would have occurred were they to keep her at thirteen, but still the scene is presented in such a way that the viewer feels as though Dany is raped. In the novel, Drogo asks, "No? . . . and she knew it was a question. She took his hand and moved it down to the wetness between her thighs. 'Yes,' she whispered as she put his finger inside her." $" 64$ On the other hand, the show presents this moment with him telling her "No"65 to make her stop crying, undresses her, then pushes her onto her hands and knees as she cries. The next time the audience meets Dany she is told by Ser Jorah, a loyal friend and exile of the Seven Kingdoms, "It'll get easier." 66 The novel says, "every night, some time before the dawn, Drogo would come to her tent and wake her in the dark, to ride her as relentlessly as he rode his stallion. ... Day followed day, and night followed night, until Dany knew she could not endure a moment longer. She would kill herself rather than go on." ${ }^{, 67}$ In both versions, she is miserable, and beyond Ser Jorah's words, the audience is the only one to offer sympathy or see what is happening as wrong.

As the story progresses, Martin gives the reader hope by providing Dany a source of strength, the dragon eggs given to her as a wedding present. The novel presents this strengthening better than the show, which only hints at it by her looking at the eggs and other moments when she interacts with them. The novel has dream sequences where she sees the dragons and their fire burns, purifies, and strengthens her ${ }^{68}$. She becomes accustomed to the Dothraki way of life, eventually asking one of her handmaids to teach her how to please the khal, succeeding in changing their sexual intercourse, allowing for both of them to enjoy it. ${ }^{69}$ Soon she sees the Dothraki as her own people and herself as the khaleesi, or Queen of the tribe. After this moment her relationship with the khal is loving and mostly egalitarian, she becomes empowered as she embraces and takes command of her sexuality, as well as her life. She becomes bold, and loses the fear she held for her abusive brother and sees the folly in his dreams of taking back the kingdom, knowing that he could never be an effective leader.

Dany is not only Queen, but also Warrior, due to demands of the barbaric and nomadic Dothraki culture. She quickly learns she cannot be gentile here, but must assert herself. She witnesses her brother's death impassively stating, "He was no dragon . . Fire cannot kill a dragon." After an attempt on her life, she is finally able to convince Drogo to cross the sea and reclaim her kingdom. To fund this, the khalasar raids and pillages other tribes and towns, getting slaves and supplies. Witnessing this, Dany reminds herself, "I am the blood of the dragon. . . This is war, this is what it looks like, this is the price of the Iron Throne." "However, she cannot stand the abuses she sees calling, "I want no rape." 72 She proceeds to claim all the women of the village: "'You cannot claim them all, child,' Ser Jorah said, the fourth time they stopped, while the warriors of her khas herded her new slaves behind her. 'I am khaleesi, heir to the Seven Kingdoms, the blood of the dragon . . . It is not for you to tell me what I cannot do.",73 In this moment, she not only asserts her authority over the warrior men of her khalasar, but also defies the men and blood brothers of Drogo in order to protect the women. This moment happens identically in the show, and in both cases, she is able to defend her actions to Drogo when the men protest, yet Drogo attributes her strength to their son in her womb rather than any womanly power of her own. This belittles her strength and credits it to a man rather than acknowledge that she is strong on her own.

She proves her true feminine strength when Drogo falls due to an infected wound. She takes charge and does everything she can for him, losing everything by the end. Her husband is in a vegetative state, she eventually kills him in sorrow; her son is stillborn and comes out monstrous and rotting as payment for Drogo's life. Finally, the khalasar abandons her, as their leader is dead. After all of this Dany does not give up, but begins anew: "All her fear was gone, burned away . . . My son is dead ... All the grief has been burned out of me . . . If I look back I am lost." 74 This last statement becomes her mantra as she goes forward. She vows to all who could hear: "I am Daenerys Stormborn, Daenerys of House Targaryen, of the blood of Aegon the Conqueror 
and Maegor the Cruel and old Valyria before them. I am the dragon's daughter, and I swear to you, these men will die screaming." 75 She has repeatedly asserted herself in this manner throughout the show and novel and each time does so with further effect and strength. Her final act is to burn Drogo's body, the traitorous witch, and the three dragon eggs. Before she walks into the blaze, at the end of it all, she calls to those who remained behind: "You will be my khalasar . . . Take off your collars. Go if you wish, no one shall harm you. If you stay, it will be as brothers and sisters, husbands and wives . . . I was a child yesterday. Today I am a woman. Tomorrow I will be old. To each of you I say, give me your hands and your hearts, and there will always be a place for you." 76 She walks into the blaze saying, "I am the dragon's daughter" 77 and the next morning she is alive, unscathed, naked but holding three hatched dragons. Seeing her like this all who had gathered fell to their knees "and Dany had only to look at their eyes to know that they were hers now ... as they had never been Drogo's." ${ }^{, 78}$ In this moment, she transcends her role of Mother to become a Warrior Queen and Mother of dragons and all those who would be her khalasar: "This later Daenerys owns the stage like perhaps no other character in the series - a woman in full control of her actions, upending the world, waging war, trampling on convention, responsible only to herself." love as a Mother to become something even greater than the masculine warrior-husband that preceded her, a Warrior Queen and Mother of Dragons, the only woman in the story's world who is completely independent and empowered to do as she wishes.

\section{Conclusion}

Fantasy has not always been kind in its depictions of women, such as its damsels-in-distress, passive ladies who do little but fill in the background space of the castle, or serving only as possessions who produce heirs for their lords. However, as society changes, so too must the literature it produces. Martin has already established strong and empowered women in his novel, yet in the show adaptation these women have often gained more strength, as fifteen years later he is now catering to a society whose standards for television have changed and is now able to have leading women who are strong, without objectifying them. These five women each allow the audience to view a range of pressures, trials, and situations that modern viewers deal with. Cersei, Catelyn, Dany, Sansa, and Arya all exhibit different archetypal traits and all face unique trials and obstacles and threats to their positions and power. Cersei's presentation is of greatest note through her adaptation to the screen as she went from being a voiceless character loathed by all in the novel, to a developed woman who cares deeply, if twistedly, for her children. Catelyn is a mother figure who loses control over her son. By the end, he only seeks her counsel when he feels he needs it. Sansa, Arya, and Dany's characters were all older than their novel counterparts, showing a society that does not want to think about children in the situations these three women faced. Sansa's effeminate nature shone through, but her romantic ideals are lessened for the sake of keeping the audience's sympathy, while Arya's tomboy rebelliousness resonates so perfectly with modern culture that she changed very little from novel to screen. Dany's transition was a bit different as they changed her initial relationship with Drogo. Yet, her strength of character in the novel carried over well on screen showing her to be a noble, just, and strong woman even after losing everything. Allowing for this change, Martin reveals how society is more open to strong women, and looks for complex characters, but feels that children should still never have to experience the horrors of war nor the trials of an adult sexual relationship. In the end, he shows that while our culture has changed over the past fifteen years, there is still plenty of progress to be made before the Aryas of the world can wield their swords without needing to become men.

\section{Acknowledgements}

I would like to thank Hannah Ditlefsen, Dr. Michelle Parkinson, and Dr. Annette Klemp at the University of Wisconsin-river Falls.

\section{References}

Benioff, Daivd, and D. B. Weiss. "Baelor" \& "Fire and Blood." Game of Thrones. Televison. Directed by Alan Taylor. Produced by Frank Doelger and Mark Huffam. Home Box Office. 2011.

Benioff, David, and D. B. Weiss. "Lord Snow" \& "The Wolf and the Lion." Game of Thrones. Television. Directed by Brian Kirk. Produced by Frank Doelger and Mark Huffam. Home Box Office. 2011.

Benioff, David, and D.B. Weiss. "The Kingsroad." Game of Thrones. Television. Directed by Timothy Van Patten. Produced by Frank Doelger and Mark Huffam. Home Box Office. 2011.

Benioff, David, and D.B. Weiss. "Winter is Coming." Game of Thrones. Television. Directed by Timothy Van Patten. Produced by Joanna Burn, Frank Doelger and Mark Huffam. Home Box Office. 2011.

Benioff, David, and D.B. Weiss. "You Win or You Die." Game of Thrones. Television. Directed by Daniel Minahan. Produced by Frank Doelger and Mark Huffam. Home Box Office. 2011.

Cogman, Bryan. "Cripples, Bastards, and Broken Things." Game of Thrones. Television. Directed by Brian Kirk. Produced by Frank Doelger and Mark Huffam. Home Box Office. 2011.

Espenson, Jane, David Benioff, and D.B. Weiss. "A Golden Crown." Game of Thrones. Television. Directed by Daniel Minahan. Produced by Frank Doelger and Mark Huffam. Home Box Office. 2011.

Jacoby, Henry. Game of Thrones and Philosophy. New Jersey: John Wiley \& Sons Inc, 2012.

Martin, George R. R. A Game of Thrones. New York: Bantam Books, 1996.

Martin, George R.R. "The Pointy End." Game of Thrones. Television. Directed by Daniel Minahan. Produced by Frank Doelger and Mark Huffam. Home Box Office. 2011.

Moore, Pearson. Game of Thrones Season One Essays. Inukshuk Press, 2011.

Tolmie, Jane. "Medievalism and the Fantasy Heroine." Journal of Gender Studies 12, no. 2 (2006): 145-158. 


\section{Endnotes}

${ }^{1}$ Goguen, Susan. "“There are no true knights': the injustice of chivalry." Game of Thrones and Philosophy, p. 217.

2 Jacoby, Henry, Editor. Game of Thrones and Philosophy. (New Jersey: John Wiley \& Sons Inc, 2012); Moore, Pearson. Game of Thrones Season One Essays. (Inukshuk Press, 2011).

${ }^{3}$ George R. R. Martin. A Game of Thrones. (New York: Bantam Books, 1996), p. 27.

${ }^{4}$ Ibid.

${ }^{5}$ Ibid., p. 40.

${ }^{6}$ David Benioff and D.B. Weiss. "Winter is Coming." Game of Thrones. Television. Directed by Timothy Van Patten. Produced by Joanna Burn, Frank Doelger and Mark Huffam. (2011).

${ }^{7}$ David Benioff, and D. B. Weiss. "Lord Snow." Game of Thrones. Television. Directed by Brian Kirk. Produced by Frank Doelger and Mark Huffam. (2011).

${ }^{8}$ Martin, Game of Thrones, p. 155.

${ }^{9}$ David Benioff, and D. B. Weiss. "Lord Snow."

${ }^{10}$ Benioff and Weiss. "Lord Snow".

${ }^{11}$ Ibid.

${ }^{12}$ David Benioff, and D. B. Weiss. "The Wolf and the Lion." Game of Thrones. Television. Directed by Brian Kirk.

Produced by Frank Doelger and Mark Huffam. (2011).

${ }^{13}$ Ibid.

${ }^{14}$ Ibid.

${ }^{15}$ Ibid.

${ }^{16}$ Ibid.

${ }^{17}$ Martin, Game of Thrones, p. 155, 427.

${ }^{18}$ Ibid., p. 429.

${ }^{19}$ Ibid., p. 429-430.

${ }^{20}$ David Benioff and D.B. Weiss. "You Win or You Die." Game of Thrones. Television. Directed by Daniel Minahan. Produced by Frank Doelger and Mark Huffam. (2011).

${ }^{21}$ Ibid.

${ }^{22}$ Ibid.

${ }^{23}$ Martin, Game of Thrones, p. 485.

${ }^{24}$ Ibid., p. 486.

${ }^{25}$ Ibid., p. 488.

${ }^{26}$ Ibid., p. 488

${ }^{27}$ Ibid., p. 488.

${ }^{28}$ Ibid., p. 488.

${ }^{29}$ Anglberger, Albert J. J. \& Alexander Hieke. "Lord Eddard Stark, Queen Cersei Lannister: moral judgments from different perspectives." Game of Thrones and Philosophy, p. 88 .

${ }^{30}$ Martin, Game of Thrones, p. 487.

${ }^{31}$ David Benioff and D.B. Weiss. "The Kingsroad." Game of Thrones. Television. Directed by Timothy Van

Patten. Produced by Frank Doelger and Mark Huffam. (2011).

${ }^{32}$ Ibid.

${ }^{33}$ Ibid.

${ }^{34}$ Ibid.

${ }^{35}$ Daivd Benioff and D. B. Weiss. "Fire and Blood." Game of Thrones. Televison. Directed by Alan Taylor. Produced by Frank Doelger and Mark Huffam. (2011).

${ }^{36}$ Martin, Game of Thrones, p. 795.

${ }^{37}$ Ibid., p. 795.

${ }^{38}$ Ibid., p. 24
${ }^{39}$ Ibid., p. 796

${ }^{40}$ Benioff and Weiss. "Fire and Blood".

${ }^{41}$ Goguen, "“There are no true knights': the injustice of chivalry," p. 211.

${ }^{42}$ Martin, Game of Thrones, p. 366.

${ }^{43}$ Ibid., p. 606.

${ }^{44}$ Ibid., p. 69.

${ }^{45}$ Ibid., p. 143

${ }^{46}$ Benioff and Weiss. "The Kingsroad".

${ }^{47}$ Ibid.

${ }^{48}$ Martin, Game of Thrones, p. 743.

${ }^{49}$ Ibid., p. 746.

${ }^{50}$ Goguen, “"There are no true knights': the injustice of chivalry," p. 206.

${ }^{51}$ Ibid., p. 749.

${ }^{52}$ Ibid., p. 70-71.

${ }^{53}$ Benioff and Weiss. "Lord Snow".

${ }^{54}$ Ibid.

${ }^{55}$ Bryan Cogman. "Cripples, Bastards, and Broken Things." Game of Thrones. Television. Directed by Brian Kirk.

Produced by Frank Doelger and Mark Huffam. (2011).

${ }^{56}$ Cogman, "Cripples. ..."

${ }^{57}$ Ibid.

${ }^{58}$ Benioff and Weiss, "Winter is Coming".

${ }^{59}$ Goguen, "“There are no true knights': the injustice of chivalry," p. 212.

${ }^{60}$ Martin, Game of Thrones, p. 73.

${ }^{61}$ Benioff and Weiss. "Lord Snow"

${ }^{62}$ Martin, Game of Thrones, p. 32.

${ }^{63}$ Jane Tolmie. "Medievalism and the Fantasy Heroine." Journal of Gender Studies 12, no. 2 (2006), p. 155.

${ }^{64}$ Martin, Game of Thrones, p. 108.

${ }^{65}$ Benioff and Weiss, "Winter is Coming".

${ }^{66}$ Benioff and Weiss. "The Kingsroad".

${ }^{67}$ Martin, Game of Thrones, 228.

${ }^{68}$ Ibid.

${ }^{69}$ Benioff and Weiss. "The Kingsroad".

${ }^{70}$ Martin, Game of Thrones, 500; Jane Espenson, David Benioff, and D.B. Weiss. "A Golden Crown." Game of Thrones. Television. Directed by Daniel Minahan. Produced by Frank Doelger and Mark Huffam. (2011).

${ }^{71}$ Martin, Game of Thrones, p. 667

72 Ibid., p. 668.

${ }^{73}$ Ibid., p. 668-669.

${ }^{74}$ Ibid., p. 755, 756, 757.

${ }^{75}$ Ibid., p. 758

${ }^{76}$ Ibid., p. 800.

${ }^{77}$ Benioff and Weiss. "Fire and Blood".

${ }^{78}$ Martin, Game of Thrones, p. 806.

${ }^{79}$ Sigrist, Michael J. "Fate, freedom, and authenticity in $A$ Game of Thrones." Game of Thrones and Philosophy, p. 224225. 